\title{
Cultural Muslims: Background Forces and Factors Influencing Everyday Religiosity of Muslim People
}

\author{
Selman Yılmaz
}

\begin{abstract}
Most observers of the science of religion define Islam as a monolithic religion. Some people pinpoint a cultural practice from a Muslim-majority country and generalize it as a practice of all Muslims around the world by assuming that Islam is a monolithic religion. In fact, Islam never meant the same thing to all Muslims. While the majority of Muslims agree on the core tenets of Islam, Muslims across the world differ significantly in their levels of religious commitment and openness to multiple interpretations of their faith. In addition, fluctuation on the core tenets of Islam among Muslim majority countries suggest that some Muslims make religion a part of their cultural life and practice religion as a cultural habit. There are many points that cultural and religious practices are mixed. This study helps to acknowledge the relationship between regional culture and religious culture, and background reasons of common everyday activities of Muslim people.
\end{abstract}

Keywords: Popular religion, Everyday religion, Popular Islam, Perception of religion, Cultural Muslim, Cultural Attitudes in the Muslim world

\footnotetext{
'Selman Yılmaz, Ph.D., is a faculty member of the Faculty of Divinity at Ankara University. Corresponding address selyilmaz@ankara.edu.tr
} 


\section{Introduction}

This study examines background reasons of common everyday activities of Muslim people as well as the relationship between regional culture and religious culture.

Everyday religion, popular religion, folk religion, unofficial religion, lived religion, common religion, religious populism and some other concepts such as implicit religion, as approached by Bailey, invisible religion, by Luckmann, and civil religion, by Bellah—all of these terms point to a dimension of religious life that suggests a differentiation between the religion of ordinary people and the religion of theologians, reverends, and other religious professionals.

Official religion tends to be the religion of elite, those who exercise effective power and therefore dominate a society. These groups hold religious institutions like mosques, churches, synagogues, temples, and councils and effectively determine what religion actually is (Lippy, 1994: 1-5).

On the other hand, popular religion reflects the lived and unstructured religion of ordinary people and is term that has developed mainly in contrast to institutionalized, established, and official religion. Nevertheless, restricting its reference purely to vulgar, superstitious, irrational, and retrograde is unfair (Possamai 2011: 249). Therefore, popular religion is not an alternative, opposite, parallel, or independent religion of the official religion (Zaccaria, 2010: 5; McGuire 2008: 45). It represents religion's ongoing and dynamic relationship with the realities of everyday life (Orsi, 1997: 7). Religion is not for scholars only. It is something to live by and die by (Corn, 1942: 77).

Since many academic disciplines, including social sciences (anthropology, psychology, sociology), religious studies (historical, comparative), and theology, contributed understanding of popular religion, examples of terminological disagreements increase (Zaccaria, 2010: 3).

According to Bruce David Forbes, there are at least four different relationships between religion and popular culture: 1. Religion in popular culture, 2. Popular culture in religion, 3. Popular culture as religion, and 4. Religion and popular culture in dialogue (Forbes, 2000: 10; also see Chidester, 2005: 30-51).

Religion in popular culture refers to the appearance, explicitly or implicitly, of religious themes, language, imagery, and subject matter in elements of popular culture (e.g. themes in 
movies, sports, advertising, entertainment, music, social media, and games). Religion penetrates these areas that are considered secular.

Popular culture in religion refers to consciously or unconsciously borrowing examples, images, languages, themes, and assumptions from popular culture as tools for religion's purposes. In other words, this category refers to the appropriation of aspects of popular culture by religious groups and institutions. One question may arise that if so much borrowing of customs and regional culture occur, how can a religion continue its uniqueness? Once a custom is accepted into a religion's system, it adapts to that system and becomes an integral part of it through time and usage (Joseph-Witham, 1998: 198).

Popular culture as religion means that popular culture sometimes serves as religion or functions like religion for many people. Adam Possamai coined the term "hyper-real religion" to refer to a simulacrum of a religion created out of popular culture (Possamai, 2012: 19-20). Examples include Jediism, from the Star Wars films, and Matrixism, from the Matrix films.

Religion and popular culture in dialogue means that religion and popular culture influence each other simultaneously.

The mingling of religion and popular culture can be a result of social reality or a product of a deliberate intention.

National churches in Christianity such as the Church of England, Armenian Church, Syriac Church, and Chaldean Church are among examples how popular culture may shape religion. In Islam, differences between Sunnis and Shiites can be explained by popular culture too.

The interaction between religion and popular culture are mostly a slow process and not easy to realize their effects on each other in a short period of time. However, in some cases there would be a deliberate action to design this interaction. For instance, in the early years of the new Republic of Turkey from 1920s through 1950, the rulers of Turkey endorsed secularist nationalism and presented a top-down social engineering project. These elites had minimized or reduced the role of religion in the country by abolishing the caliph in 1924; closing dervish lodges and Islamic monasteries in 1925; leaving Arabic scripts in the Turkish alphabet for Latin in 1928; revoking the second section of the Constitution that mentioned "the official religion of Turkey is Islam" in 1928; reciting azan in Turkish instead of Arabic between 1932-1950; banning the veil and fez in 1934; changing the weekend vocation from Friday to Sunday in 1935; and constitutionalizing that "Turkey is a secular state" in 1937. 
Therefore, the Turkish state imposed a secular religiosity where local and national values came to prominence (Gunduz, 2010: 30-33). Turkish azan and pray were the most extreme examples to show how this new religiosity was shaped in that times. Although the early rulers of Turkey tried to shape a secular and nationalist Turkish Islam, they mostly failed. Majority of population did not respect these changes and continued their old beliefs and practices as usual.

Majority of the Muslim countries in the MENA (Middle East and North Africa) region have gone through experiences similar to Turkey's. When they achieved independence from colonial rule, the states took over many institutions of religious learning and training to use them for their own nationalist projects (Yilmaz, 2013: 16, 34; for Egypt see Berger, 1970: 44).

Other Muslim countries, which are outside of the MENA region, have experienced similar problems too. In the Indonesian case, the state policy obliged all political and mass organizations to replace their religious-ideological foundations with the state ideology Pancasila $^{i i}$ (Saleh, 2001: 301). When East Pakistan (Bangladesh) gained her independence from West Pakistan in 1970s, the common bond of Islam was no longer emphasized and replaced by common linguistic heritage, invented secular traditions, ethnicity, and secular nationalism (Uddin, 2006: 121-123). After the collapse of Communism, Central Asian governments have sought ways to control Islam and exploited Islamic elements for their state-building projects and used Islam as source of legitimacy (Louw, 2007: 33). In some cases such as Tajikistan, governments fabricated a pre-Islamic landscape of an official collective memory to erode Islamic elements from their national identities (Epkenhans, 2011: 81) that caused spreading of popular elements through Islam.

However, aforementioned examples do not mean that social realities have no influence on religions. The four categories between religion and popular culture suggest that religion and popular culture have a constant interactive relationship.

Among these categories, the impact of popular culture upon religion has been the least examined (Forbes, 2000: 13). It is more difficult to see the popular culture in religion than other categories. Without comparing different cultures, researchers may fail to find the origin of some religious behaviors and may assume that these behaviors came from religious orders even though

\footnotetext{
ii (Indonesian from Sanskrit) A formulation of five principles put forward by Sukarno in 1945 as the philosophic basis for an Indonesian state and the official ideology of the state after 1958. The principles are "Belief in God," "humanitarianism," "nationalism," "democracy," and "social justice."
} 
they are reflections of culture. The analysis of popular culture can provide insights about how religions can change and are changed by the cultures that surround them (Yilmaz, 2013).

For instance, showing respect to religious themes is a mutual aspect of all cultures. However, representing this respect might differ among cultures. A Turkish person shows this respect in mosques by not lying, playing, and talking in them. One of my professors mentioned a personal experience about it. When he was in Saudi Arabia for umrah in 1990s, he witnessed a child was playing inside a mosque. Immediately he warned the child to be quite and sit appropriately. After a while, this professor realized that many people were lying around the mosque and sleeping, children were playing freely. These behaviors were very different than be seen in mosques in Turkey. He questioned whether he made the right choice by warning this child. These behaviors conflicted with Turkish cultural codes but not necessarily meant disrespect to mosques. Moreover, in recent years these cultural codes regarding mosques have become more tolerated. Therefore, this study is useful to compare how Muslim countries differ from each other in religious codes and about their implementation.

The tension between popular and formal elements in a religion is not only endemic in the present time but a problem of centuries and goes back to early times. It appeared in early Islam as well as is found in other religions (Berger, 1970: 73). For instance, seventy years ago, I. S. Corn were complaining on this issue for Christianity. According to him, it was a practical problem that trying to bridge the gap between what the scholars know and teach about the Bible and religion and what the people believe and live by. Illustrating, when a father has died neither the mother nor the children care much for the distinctive characteristics of the various religious texts or manuscripts. What they want is some solid substance of comfort, which comes from sure confidence in the goodness of God and the hope for the afterlife (Corn, 1942: 77-78).

Charles Lippy explains this phenomenon by the need of ordinary people for simpler, more direct, and more practical access to the divine than the trappings of formal religion offer. Accordingly, popular religion may include both formal religious tradition and the beliefs and practices that come from other sources (Lippy, 1994: 4).

\section{Discussions}

The sources that shape everyday Islam of Muslim people include: 
1) Ancient beliefs and customs of nations; 2) Other cultures and religions that lived in the same region; 3) Gaza (holy war) Islamism; 4) Sufism; 5) Authoritarian States; and 6) Modernization (see Arslan, 2004: 133-140; Gunduz, 2010: 27-37).

1) Ancient beliefs and customs of nations: When people convert to a new religion, they do not completely leave their old habits. Charles Lippy questions this phenomenon with an example from Christianity. When pagans converted to Christianity, they fused their old beliefs and practices with formal Christianity and forged a popular religiosity. For instance, the precise date of the birth of Jesus is unknown, but that fixing it on 25 December coopted the importance attached to winter solstice festivals among the people. The medieval fascination with relics of the saints, the continuing affirmation of the power of witchcraft, and even such devotional practices as pilgrimages represent other examples. Therefore Lippy questions whether Roman Empire became a Christian empire or Christianity became a Roman religion (Lippy, 1994: 14).

Islam does not have an exception on this rule. For instance, when Javanese have accepted Islam since the fourteenth century, they adapted Islam to the main configurations of the preexisting Javanese religion. Islam did not create many significant changes in the Javanese worldview in those times (Saleh, 2001: 36). Clifford Geertz describes the Javanese variant of Islam, abangan, with its syncretic futures (Geertz 1976). Therefore, Indonesian Islam has distinctively reflected forms and moods of the Hindu past (Voll, 1994: 63). Such a case did not happen to Malaysian Muslims, whom Islam became an identity referent. While Malay means to be a Muslim because of Malaysian Muslims' deep integration with Islam, Javanese does not necessarily mean to be a Muslim (Saleh, 2001: 37). In Africa, as in Indonesia, Islam challenged syncretistic and latitudinarian religions and infiltrated into dominant groups, in a process that managed to the Islamization of the state and the society. The agency of syncretism led Islam to reconcile with older traditions in an ongoing process of reconstructing social and religious identities (Insoll, 2004: 101; Gunay, 2001: 354). Therefore, pre-Islamic structures, customs, and beliefs survived. People adopted Islam into their own social and cultural milieus (Levtzion, 2007: VII).

It was the same in Central Asia. Before Islam penetrated into the region, Central Asia composed different religious trends from paganism to syncretism. Manichaeism, Nestorian Christianity, Zoroastrism, Buddhism, and shamanism lived in the region for centuries. After Islam, the Islamic law coexisted with shamanism and other pre-Islamic religions. Especially, nomads developed Islamic practices of their own (Polonskaya and Malashenko, 1994: 33). Some 
religious rituals became a combination of shamanism, Islamic beliefs, and indigenous tribal culture (Maghsudi, 2013: 112). Specifically, the healing rituals are examples of this syncretism where a number of classic elements of Siberian and Mongolian shamanistic practices appear in the role of fire, signs, sickness, protectorate spirits, and travel in search of evil spirit. They have been observed among Kazakhs, Kyrgyz, Uzbeks, Turkmens, and Uyghurs (Dupaigne, 2013: 125).

The same ancient beliefs of Central Asia influenced people of Turkey (Ocak, 2010: 53111) although they migrated to Anatolia hundreds years ago. Even though shamanism is more Islamized in Turkey than in Central Asia (Zarcone, 2013: 195), effects of it are visible especially in Bektashi religious stories (Ocak, 1984: 70). Alevi beliefs in Turkey are a living example of this syncretism (Oktem, 2011: 13-35).

However, effects of ancient beliefs should not be exaggerated. According to Bruce G. Privratsky, in the case of Kazak beliefs, effects of shamanism on Muslim Kazak beliefs and syncretization of ancient shamanism and Muslim values are still questionable theories. Since most literature mention the same, literate Kazaks are influenced by these analyses. Therefore, "they describe themselves in the light not so much of their own religious experience, but of the ethnographic literature about them" (Privratsky, 2001: 10). On the same way, many Alevis reject the claim of syncretism and offer that their beliefs are coming from Islamic resources, not from a non-Islamic syncretism (Ocak, 2010: 16). Patrick Garrone describes the mingling of shamanism and Islam in Central Asia as a process of assimilation in favor of the Muslim faith rather than an established syncretism (Garrone, 2013: 18).

Since new converts of Islam wanted to embrace their new religion, they expressed Islam in the local components. For instance, Bengali Muslims used Hindu epics. Consequently, some of them depicted the prophet Muhammad as an avatar of God, assimilated Hindu ideas of yuga as periods of gestation for the divine messenger Muhammad, apotheosized Sufi leaders as guru, and depicted the prophet Muhammed as being able to bring the blessings of siddhi (fulfillment) and mukti (liberation) to his devotees (Hardy, 2002: 153).

It is easier to realize the effects of previous beliefs on new coverts. The study of Ali Kose (1997) about converted English Muslims suggests that English converts do not have fear about the afterlife, or they have little fear when we compare them to born and raised Muslims. None of these converts mentioned that when they converted to Islam, they secured their afterlife and they would go to heaven; if they did not convert, they would go to hell; or their family members who are not converted would go to hell. Even though interpretations that non-Muslims go to hell are 
very common among Muslims, we do not see this interpretation among converted Muslims (Kose, 1997: 105-106). These examples show us that interpretation of religion highly depends on cultural background.

\section{2) Other cultures and religions that lived in the same region:}

Residue of ancient cultures that dwelt in the same area is among important reasons forming popular religiosity. Raymond Williams' terms "residual and emergent cultures" are useful to explain this situation (Williams, 1980: 40-42). According to Williams, every culture is a mixture of residual and emergent forms. Residual refers to a set of experiences, meanings and values, which cannot be verified or cannot be expressed in terms of the dominant culture, but which are nevertheless lived and practiced on the basis of the residue-cultural as well as social — of some previous social formation. Emergent means that new meanings and values, new practices, new significances and experiences, are continually being created (Williams, 1980).

Two researches on Korean converted Muslims show effects of different cultural backgrounds on religion. A research that was conducted in 1985 studying 260 Korean converted Muslims indicates that 61 percent of Korean converted Muslims drink alcoholic beverages and 77 percent of them eat bacon and pork products. Another study conducted in 2001 in Korea indicates that 25 percent of Korean converted Muslims continue drinking and 16 percent of them eat bacon and pork products (Kim, 2003: 23-74). When researchers asked the reasons for these behaviors, which are definitely forbidden by Islam, converts pointed out the importance of drinking for socialization. One Korean converted explained this situation: "I couldn't leave drinking. Non-drinking seems harmful for social relations in Korea. Because of this reason, even though I do not like drinking, I drink when it seems necessary." This instance shows that the same religious prohibitions can be implemented differently in different cultures. My previous research (Yilmaz, 2006) suggests similar results: 70 percent of Turkish teachers state that they do not eat bacon or pork products. On the other hand, only 45 percent of teachers state that they do not drink because of Islamic ban. We can interpret this 25 percent differences between these two categories that implementation of religious bans highly depend on cultural and traditional background.

Another example of how religiosity depends on cultural background is that respecting for bread in Turkey. When people see a piece of bread on ground, they usually take it and put it in a corner of a building or a higher place; however, they do not show the same respect to other foods. Ali Kose explains this situation by "collective subconscious." Even though bread does 
not have any superiority to other foods in a religious sense, it takes superiority because Turkish society has lived through famine many times and bread is a primary food staple (1997: 1). As Geertz puts it, societies, like lives, contain their own interpretations (1987).

In addition, vernacular languages have helped passing of cultural residue to new generations. The Muslim elite have used Arabic and Persian languages and their scripts, while the masses have continued in regional and local languages, including Turkish, Urdu, Sindhi, Punjabi, and Bengali. This language barrier has facilitated spreading of popular elements among the masses. The expansion of Islam into the countryside widened the popular basis. The dissemination of the knowledge of Islam to the peasants could only have been done in the vernacular languages (Levtzion, 2007: 86).

\section{3) Gaza (holy war) Islamism:}

"And let there be [arising] from you a nation inviting to [all that is] good, enjoining what is right and forbidding what is wrong, and those will be the successful." (Ali Imran: 104).

Islam orders Muslims to invite people to the religion. Muslims are encouraged not only to be practicing believers but also missionaries of religion (تبلغ). Endeavors for conveying religion are encouraged. A part of these endeavors is holy wars (jihad). Muslim nations have endeavored being protector and ambassador of Islam. Some of them became more prominent among others such as Arabs and Turks. Therefore holy war related activities entered popular religion. Epic stories on courage and altruism of warriors found more place among public. People visit the tombs of these martyrs and veterans to show their respect and admire their sacrifices.

Jihad term does not only cover outer physical struggle but also inner spiritual struggle. Even spiritual part, fulfilling religious duties, named greater jihad to show its importance. How physical jihad has martyrs and veterans, spiritual jihad have its important figures as well. Saints and dervishes are among them. People visit saint tombs and shrines to show their respect to them.

Visiting tombs of martyrs, veterans, saints, and dervishes do not only stay on touristic level in plenty of cases. Some people visit them for healing, success, wealth, fame, and power. These visitors pray in these places, tie cloths and rags to tombs, rub wallets, car and house keys to walls of tombs for their wishes. Therefore they form a popular religiosity, which gradually replaces official religion. 
Although it is expressed numerous times by the departments of religious affairs in Muslim countries, by the media, and by imams in sermons, as well as written at the entrance of tombs, that many of these kinds of behaviors are superstitions, numerous people continue these deeds.

For instance at the entrance of tombs and shrines in Turkey, the Department of Religious Affairs hangs sings to warn visitors:

Attention to visitors. According to Islam, committing below mentioned and similar behaviors in the name of tombs and shrines are superstitions and definitely prohibited in Islam: offering and sacrificing animals; burning candles; tying clothes, stones, and money; entering to the tomb by bowing down and crawling; throwing money; leaving food and beverages; touching hand and face; demanding heal or any kind of help; walking around; and laying inside.

Nevertheless, people continue similar behaviors. Serif Mardin describes this situation, differences between popular religion and official religion: "It is a mistake to understand the religion [Islam] from publications of the Department of Religious Affairs [in Turkey]. Religion is what families teach their children" (Mardin, 1992: 64). This statement shows us that religious doctrine and religion in daily life do not always get along with each other. We can describe this fact, differences between official and unofficial religion, as everyday religion.

\section{4) Sufism}

The mystical orders are another nodal point that facilitates shaping of popular religion. Islam does not have a single religious authority that gives direction and context to the Islamic tradition. Therefore every Muslim is responsible to refer directly to the sources of religion, Quran and the Sunnah-deeds and words of the Prophet Mohammed. Since appealing to the primary sources of Islam is not practical for the majority of Muslims, they pursue the paths of prominent Muslim scholars. Since individual understandings of primary sources can vary greatly from person-to-person and time-to-time, popular religion finds ways to penetrate Islam while new interpretations of Islam occur.

In addition, the esoteric character of studies of the Muslim scholars encouraged popular movements to produce their own men of authority (Sharot, 2001: 203). 'He who has no sheikh has the devil for his sheikh' became a popular saying. The masses have looked to the great leaders of the faith as well as their local leaders for guidance (Voll, 1994: 21). 
Last but not least, Islam spread out of the MENA region by help of Sufism where it blended and localized with local mystical practices. During the early conversions, syncretic popular Islam celebrated local ideas, beliefs, values, and practices (Weintraub, 2011: 3).

\section{5) Authoritarian States}

The persistence of authoritarian regimes in Islamic region, the recent colonial rule, and anti-colonial struggles have influenced everyday religion. As I gave its examples before, authoritarian rulers imposed a secular religiosity where local and national values came to prominence. The production of state-sanctioned piety helped flourishing of new forms of popular religion (Pinto, 2004: 185). Therefore, some people have perceived saint cults as part of the decadence of colonial rule and are thereby susceptible to Western conquest and cultural influence (Sharot, 2001: 203). New reformist movements, such as Muhammadiyah and Persetuan Islam movements in Indonesia, Jamaat Tabligh and Darul Arqam in Malaysia, and the Muslim Cultural Union in West Africa, erupted to purify Islam from local influences and practices (Saleh, 2001: 3; Voll, 1994: 347; and Soares, 2004: 215). These movements sharpened the sense for a purer Islam, less contaminated with either animism or mysticism (Geertz, 1976 [1960]: 6). Although these kinds of movements claim to bring a purer Islam, they retain their own respective interpretations of what it means to be the pristine Islam.

On the other hand, popular religion may represent a sigh of oppressed religious populations under authoritarian regimes where official religion is strictly controlled by the state (Arslan, 2006: 313; 2008: 76). Hence, elements of popular religion can be observed during the religious revitalization movements after the 1960s.

Communism in the Soviet Union have affected beliefs of Muslim nations in the Central Asia such as Azeri, Bashkir, Chechen, Kazakh, Kyrgyz, Tajik, Tatar, Turkmen, and Uzbek. 70 Soviet years of the Iron Curtain broke the collective memory of the Muslim identity and restricted public religious practices. Religious properties were confiscated, mosques and madrasas were destroyed or closed, and the Muslim scholars were persecuted. During the Second World War, this repression had revealed someway to gain popular support. In those years, the Soviet government allowed establishing of the Spiritual Administration of the Muslims of Central Asia and Kazakhstan. This body monitored mosques and other supervised other religious activities. However, the main part of the population was still under restrictions to attend official mosques. Islam was isolated from the wider Muslim world. Unregistered mosques and madrasas functioned clandestinely. Therefore, official Islam did not penetrate to public level. Even if some 
practices continued, they were nationalized as their examples can be seen in rituals related to marriage, birth, and death. Islam became a synonymous of tradition and a marker of national identity that does not include any personal piety or observance. (Louw, 2007: 1-4; 21-22).

\section{6) Modernization}

Majority of the founding figures of modern social science-including Auguste Comte, John Stuart Mill, Herbert Spencer, Ferdinand Toennies, Georg Simmel, Emile Durkheim, Max Weber, Karl Marx, and Sigmund Freud-believed that modernization-the process of industrialization, urbanization, and raising levels of education and wealth-greatly weakens the influence of religious institutions in modernizing societies and erodes the role of religion in society and in the minds of individuals (Yilmaz, 2013: 23). Therefore, modernization theories natively include secularization of nations during modernization period. However, years have shown us modernization is not necessarily associated with secularization. Moreover, modernization has helped religious revivalism in some countries by undermining state-controlled religion with tools of education and communication.

In addition, modernization has helped forming of popular religion in some way. Most literature on popular religion focuses on effects of previous beliefs on popular religion (see Arslan, 2006: 302). They ignore effects of contemporary developments. I can compile a bundle of present-day effects on popular religion under the name of modernization.

Urbanization, as a part of modernization, is one of these effects. At first glance, as Ernest Gellner suggests, urbanization, political centralization, incorporation in a wider market, and labor migration impel populations from Folk Islam to High Islam (Gellner 1992: 15). However, a closer look reveals that while urbanization removes previous folk beliefs, it forms its own popular religiosity in the same time.

The weakening of the boundaries and identities of local communities in societies does not necessarily result in the disappearance of popular religion (Sharot, 2011: 242). Urbanization may weak the kinship structure but induces people to seek solidarity by returning to traditional religious institutions such as Sufi orders (Berger, 1970: 75). Therefore, urbanization and its socio-economic problems foster popular religion and new religious movements (Celik, 2006: 104-106). Alienated masses vitalize religion. As mentioned Karl Marx's famous quote, if religion functioned "the sigh of the oppressed creature, the heart of a heartless world, and the soul of soulless conditions. It is the opium of the people" (Marx, 1972: 54); then, the opium is indeed required for the urban people, the popular religion serves better than scholarly theology 
(Gellner, 1992: 12). When these masses revitalize religion, they compose new forms of popular religion in forms of Sufi orders, shrines, and saint cults. A new kind of religiosity that is peculiar to the month of Ramadan can be an example of urban popular religion.

Effects of labor migration can be seen on Muslim immigrants of Western Europe. In there, everyday Islam represents a negotiation between Islamic values and non-Islamic traditions. While Islam handed down by generation to generation in the form of practice, everyday Islam endorsed a social and political integration in this relatively new multi-religious society (Alam, 2007: 254).

Revival of the Turkish Alevi identity in the twentieth century and the Javanese syncretism from the late nineteenth century towards the late twentieth century are other examples regarding effects of urbanization and rural-to-urban migration on popular religion (Bruinessen, 2009: 147-148). Alevi rituals were connected with the village community. When Alevi masses left their villages for urban life, they gave up religious practices. In the urban life, they either adapted practices of the Sunni majority, or more commonly became non-practicing secular Muslims. However, during the following years they have experienced a revival in the urban environment and developed a consciousness to learn and practice their beliefs and rituals. They clustered in urban neighborhoods against discrimination and raised awareness for the Alevi identity.

In the case of the Javanese syncretism, previously I mentioned that some Islamic movements aimed to purify Islam from local influences. However, in some cases, this effort backfired. Many syncretistic mystical teachers took a negative attitude towards scriptural Islam and distanced themselves from the reformist Muslim groups or from Islam altogether.

In Central Asia, after the independence of Kazakhstan, bakhsi (shaman-Sufi) practices, which are linked to new forms of popular Islam, reappeared spontaneously (Vuillemenot 2013: 59). Similarly, many of the people from younger generations turned back to esoteric healers because of the lack of a good healthcare system across the region after the collapse of the Soviet regime. These healers legitimized their activities through the religion (Kara, 2013: 55).

Secular consumerism and globalization are other elements that help expanding of popular religion during modernization (Barbalet, Possamai, and Turner, 2011: 280). When I was a teacher in a public elementary school, I witnessed that when students want a favor from their teachers, several of them bow their heads and fold their hands-like how Christians pray. Although these students are completely Muslims, they were unaware that they imitate Christian 
religious behaviors where they see on Hollywood movies. Therefore new popular religious elements penetrate into Islam without realizing them under the influence of globalization.

The increasing open and accessible forms of communication by means of media, social media, and internet, play a significant role in fragmenting and contesting religious authorities. This new situation creates a Muslim public sphere where religious, political, and social life mix in modern times (Eickelman and Anderson, 2003: 1).

Last but not least, modernization raises level of education. At first sight, education has a negative effect on popular religion. In practice, it has also brought some problems. During the late twentieth and twenty-first centuries, education has gained a dualistic structure in Muslim majority countries by divided between religious and secular education. Madrasah education, which ran mostly by civil servants and out of state control, undertook Islamic education on the one hand, general schools undertook secular education, which administered by the state departments, on the other hand. Because of this dichotomy, madrasah lost their financial support, professional teachers, and qualified students. In the long run, these problems have affected interpretation of religion and its reflections on public.

In short, religion is not independent from its social and cultural context (Cusack, 2010: 20-21). Therefore, we can still see effects of social and cultural codes on religion in modern times. In summary, the expressions of theoretical and practical religion are firmly dependent on each other. First the theoretical part, then the practical part (practices) occurs; however, the theoretical part follows the practical in time.

\section{Conclusion}

In this paper, I examined background reasons of common everyday activities of Muslim people as well as the relationship between regional culture and religious culture.

This study inspired by the results of the PEW Research Center's survey that was conducted in 2012 with over 38,000 Muslims around the world. The PEW's results show that large percentages of Muslims around the world share articles of faith, including there is only one God and that Muhammad is His Prophet, belief in angels, heaven, hell, and fate. While there is broad agreement on the core tenets of Islam, however, Muslims across the world surveyed differ significantly in their levels of religious commitment, openness to multiple interpretations of their faith, and everyday religiosity (PEW, 2012). Fluctuation on the core tenets of Islam among 
Muslim majority countries suggests that some Muslims make religion a part of their cultural life and they practice religion as a cultural habit.

My study suggests that ancient beliefs and customs of nations, other cultures and religions that lived in the same region, gaza (holy war) Islamism, Sufism, authoritarian states, and modernization are the most important reasons forming everyday religiosity of Muslims.

Most literature on everyday religion focuses on effects of previous beliefs. Therefore, they ignore effects of contemporary developments. I compiled a bundle of present-day effects on everyday religion under the name of authoritarian states and modernization through the paper.

\section{References:}

Alam, Anwar (2007). Scholarly Islam and Everyday Islam: Reflections on the Debate over Integration of the Muslim Minority in India and Western Europe. Journal of Muslim Minority Affairs, 27:2, 241-260.

Arslan, Mustafa (2008). Popular Islam in Modern Turkey: A Typological Approach. Hikmet Yurdu, 1:1, 71-86.

Arslan, Mustafa (2004). Türk Popüler Dindarlı̆̆ı. Istanbul: Dem Yay.

Barbalet, Jack, Adam Possamai, and Bryan S. Turner (2011). Key Issues in Modern Sociology: Religion and the State: A Comparative Sociology. London: Anthem Press.

Berger, Morroe (1970). Islam in Egypt Today: Social and Political Aspects of Popular Religion. Cambridge: Cambridge University Press.

Bruinessen, Martin van (2009). Sufism, Popular Islam and the Encounter with Modernity. In Islam and Modernity: Key Issues and Debates (ed. by Muhammad Khalid Masud, Armando Salvatore, and Martin van Bruinessen), Edinburgh: Edinburgh University Press, 125-157.

Celik, Celaleddin (2006). Kentsel Dindarlık-Kentlilik Tecrübelerinde Farklılaşan Dindarlık. In Dindarlığın Sosyo-Psikolojisi (ed. by Unver Gunay and Celaleddin Celik). Adana: Karahan Kitabevi, 81-111.

Chidester, David (2005). Authentic Fakes: Religion and American Popular Culture. Los Angeles: University of California Press.

Corn, I. S. (1942). Scholarly Religion and Popular Religion. Journal of Bible and Religion, 10:2, 76-79. 
Cusack, Carole M. (2010). Invented Religions: Imagination, Fiction and Faith. Burlington: Asghate Publishing.

Dupaigne, Bernard (2013). Shamans in Afghanistan?. In Shamanism and Islam: Sufism, Healing Rituals and Spirits in the Muslim World (ed. by Thierry Zarcone and Angela Hobart) New York: I. B. Tauris.

Eickelman, Dale (1985). Knowledge and Power in Morocco. Princeton, N.J.: Princeton University Press.

Eickelman, Dale and Jon W. Anderson (2003 [1999]). New Media in the Muslim World: The Emerging Public Sphere. Bloomington: Indiana University Press.

Epkenhans, Tim (2011). Defining Normative Islam: Some Remarks of Contemporary Islamic Thought in Tajikistan-Hoji Akbar Turajonzoda's Sharia and Society. Central Asian Survey, 30:1, 81-96.

Federspiel, Howard M. (2001). Islam and Ideology in the Emerging Indonesian State: The Persatuan Islam (Persis), 1923 to 1957. Leiden: Brill.

Forbes, Bruce David (2000). Finding Religion in Unexpected Places. In Religion and Popular Culture in America (ed. by Bruce David Forbes and Jeffrey H. Mahan). Berkeley, CA: University of California Press.

Garrone, Patrick (2013). Healing in Central Asia: Syncretism and Acculturation. In Shamanism and Islam: Sufism, Healing Rituals and Spirits in the Muslim World (Ed. by Thierry Zarcone and Angela Hobart). New York: I. B. Tauris. 17-46.

Geertz, Clifford (1987). Deep Play: Notes on the Balinese Cockfight. MN Press: Cambridge.

Geertz, Clifford (1976 [1960]). The Religion of Java. Chicago: University of Chicago Press.

Gellner, Ernest (1992). Postmodernism, Reason and Religion. London: Routledge.

Gunay, Unver (2001). Din Sosyolojisi. Istanbul: Insan yay.

Gunduz, Sinasi (2010). Nationalization of Universal Religion: Anglicanism and Turkish Islam. Milel ve Nihal, 7:3, 9-38.

Hardy, Peter (2002 [1987]). Islam in South Asia. In The Religious Traditions of Asia: Religion, History and Culture (ed. by Joseph M. Kitagawa). New York: Routledge.

Herzfeld, Michael (2005). Cultural Intimacy: Social Poetics in the Nation-State (second ed.). New York: Routledge. 
Insoll, Timothy (2004). Syncretism, Time, and Identity: Islamic Archaeology in West Africa. In Changing Social Identity with the Spread of Islam: Archaeological Perspectives (ed. by Donald Whitcomb). Chicago: The Oriental Institute.

Joseph-Witham, Heather Rose (1998). Transforming Folk Beliefs: A Community of Indian Jews in Los Angeles and the Process of Believing (Dissertation). University of California: Los Angeles.

Kara, David Somfai (2013). Religious Traditions among the Kazakhs and the Kirghizs. In Shamanism and Islam: Sufism, Healing Rituals and Spirits in the Muslim World (ed. by Thierry Zarcone and Angela Hobart). New York: I. B. Tauris. 47-58.

Kim, Heon Choul (2003). Din Değiştirmenin Entelektüel Arka Planı. Istanbul: Kaynak Yay.

Kose, Ali (1997). Neden İslam’ı Seçiyorlar: Müslüman Olan İngilizler Üzerine Psiko-Sosyolojik Bir Inceleme. Istanbul: İsam Yay.

Levtzion, Nehemia (2007). Islam in Africa and the Middle East: Studies on Conversion and Renewal. Burlington: Ashgate Publishing.

Lippy, Charles (1994). Being Religious, American Style: A History of Popular Religiosity in the United States. Westport, Conn.: Greenwood Press.

Louw, Maria Elisabeth (2007). Everyday Islam in Post-Soviet Central Asia. London: Routledge.

Maghsudi, Manijeh (2013). Two Indigenous Healing Methods among Iranian Turkmen. In Shamanism and Islam: Sufism, Healing Rituals and Spirits in the Muslim World (ed. by Thierry Zarcone and Angela Hobart). New York: I. B. Tauris. 95-114.

Mardin, Serif (1992). Din ve İdeoloji (fifth ed.). Istanbul: İletişim Yay.

McGuire, Meredith B. (2008). Lived Religion: Faith and Practice in Everyday Life. Oxford University Press.

Ocak, Ahmet Yaşar (1984). Türk Halk Inançlarında ve Edebiyatında Evliya Menkabeleri. Ankara: Başbakanlık Basımevi.

Ocak, Ahmet Yaşar (2010 [1983]). Alevi ve Bektaşi Inançlarının İslam Öncesi Temelleri. Istanbul: İletişim.

Orsi, Robert (1997). Everyday Miracles: the Study of Lived Religion. In Lived Religion in America: Toward a History (ed. by David D. Hall). New Jersey: Princeton University Press.

Oktem, Niyazi (2011). Anadolu Aleviliğinin Senkretik Yapısı. Istanbul: Truva. 
Pew Research Center. 2012. The World's Muslims: Unity and Diversity.

Pinto, Paulo G. (2004). The Limits of the Public: Sufism and the Religious Debate in Syria. In Public Islam and the Common Good (ed. by Armando Salvatore and Dale Eickelman). Boston: Brill. 181-204.

Polonskaya, Ludmila and Alexei Malashenko (1994). Islam in Central Asia. Lebanon: Garnet Publishing.

Possamai, Adam (2012). Yoda Goes to Glastonbury: a Introduction to Hyper-Real Religions. In Handbook of Hyper-real Religions: Brill Handbooks on Contemporary Religion, Volume 5 (ed. by Adam Possamai). Leiden: BRILL. 1-21.

Possamai, Adam (2011). Gramsci, Jediism, the Standardization of Popular Religion and the State. In Religion and the State: A Comparative Sociology (ed. by Jack Barbelet, Adam Possamai, and Bryan S. Turner). New York: Anthem Press. 245-262.

Privratsky, Bruce G (2001). Muslim Turkistan: Kazak Religion and Collective Memory. Great Britain: Curzon Press.

Saleh, Fauzan (2001). Modern Trends in Islamic Theological Discourse in 20th Century Indonesia: A Critical Survey. Leiden: Brill.

Sharot, Stephen (2001). Comparative Sociology of World Religions: Virtuosi, Priests, \& Popular Religion. New York: NYU Press.

Soares, Benjamin F. (2004). Islam and Public Piety in Mali. In Public Islam and the Common Good (ed. by Armando Salvatore and Dale Eickelman). Boston: Brill. 205-226.

Sufia, Uddin (2006). Constructing Bangladesh: Religion, Ethnicity, and Language in an Islamic Nation. Chapel Hill: University of North Carolina Press.

Voll, John Obert (1994 [1982]). Islam: Continuity and Change in the Modern World (second ed.). New York: Syracuse University Press.

Vuillemenot, Anne-Marie (2013). Muslim Shamans in Kazakhstan. In Shamanism and Islam: Sufism, Healing Rituals and Spirits in the Muslim World (ed. by Thierry Zarcone and Angela Hobart). New York: I. B. Tauris. 59-78.

Weintraub, Andrew N. (2011). Islam and Popular Culture in Indonesia and Malaysia. New York: Routledge.

Williams, Raymond (2005 [1980]). Culture and Materialism. New York: Verso. 
Yilmaz, Selman (2006). A Sociological Analysis of Elementary School Teachers' Perception of Religion: Istanbul Sample (M.A. Thesis). Marmara University: Istanbul.

Yilmaz, Selman (2013). State, Politics, and Religion: Effects of Political and Social Change on the Relationship Between State and Religion in Turkey, 2002-2014 (Dissertation). University of Pittsburgh: Pittsburgh.

Zaccaria, Francesco (2010). Participation and Beliefs in Popular Religiosity: An EmpiricalTheological Exploration among Italian Catholics. Leiden: Brill.

Zarcone, Thierry (2013). Shamanism in Turkey: Bards, Masters of the Jinns, and Healers. In Shamanism and Islam: Sufism, Healing Rituals and Spirits in the Muslim World (ed. by Thierry Zarcone and Angela Hobart). New York: I. B. Tauris. 169-202. 